\title{
Study of endogenous hormones in endometrial cancer patients of premenopausal women
}

\author{
G. S. R. Kedari ${ }^{1, *}$, Guru Pawan Kumar G. ${ }^{2}$, H. Ashwin Raj $^{3}$, Ratnashree Biswas ${ }^{4}$ \\ ${ }^{1}$ Professor, ${ }^{2}$ Assistant Professor, ${ }^{3}$ Tutor, ${ }^{4}$ PG Student, Dept. of Biochemistry, Saveetha Medical College, Chennai, Tamil Nadu, \\ India
}

*Corresponding Author:

Email: kedari.gsr@gmail.com

Received: $06^{\text {th }}$ December, 2017

Accepted: $07^{\text {th }}$ February, 2018

\begin{abstract}
Introduction: Several studies were conducted worldwide to estimate various endogenous hormone levels in endometrial cancer patients of post-menopausal women and very few studies were done in premenopausal women. In India, our study is the first study conducted to estimate the endogenous hormones in endometrial cancer patients of premenopausal age group.

Materials and Methods: 25 number of endometrial cancer patients were taken as cases and 50 number of age matched healthy subjects were selected as controls for this study. Total testosterone, follicular estrogen, mid luteal estrogen, luteal estrogen, and follicular progesterone, mid luteal progesterone, luteal progesterone and fasting insulin were estimated for all the subjects.

Results: Statistical significant increase were observed in the levels of testosterone, follicular progesterone, mid luteal progesterone and luteal progesterone in cases when compared to controls. No statistical significant difference were observed in follicular estrogen, mid luteal estrogen, luteal estrogen and fasting insulin levels between cases and controls.

Conclusion: From our study we conclude that endogenous hormones play a major role in the development of endometrial cancer in pre menopausal women as Testosterone is increased and progesterone is decreased in cases when compared to controls. Extensive studies are required to diagnose endometrial cancer in early stages for better prognosis.
\end{abstract}

Keywords: Estrogen, Progesterone, Testosterone.

\section{Introduction}

Endometrial cancers are the most common gynecologic cancers in developed countries with over 150,000 women diagnosed each year making the fifth most common cancer in women. ${ }^{1}$ The prevalence of this cancer is also increasing in developing countries like India. Obesity is an important risk factor for this disease in both pre and postmenopausal women, accounting for $40 \%$ of the incidence. ${ }^{2}$ Various measures of fat distribution, such as WHR, have been reported to be associated with increased risk of endometrial cancer, although less consistently than BMI.,4 The other risk factors for endometrial cancer include diabetes, hypertension, PCOD, nulliparity, infertility, endometrial polyps and estrogen replacement therapy etc. ${ }^{1}$

Epidemiological studies indicate that estrogens, both endogenous and exogenous, have a major role in endometrial carcinogenesis. ${ }^{5,6}$ Few studies have investigated a possible differential effect of BMI on endometrial cancer risk before and after menopause ${ }^{7,8}$ and a possible threshold effect in premenopausal women, whereas in older women there appears to be a linear increase with BMI. Chronic hyperinsulinemia is clearly another important risk factor for endometrial cancer among both pre and postmenopausal women. ${ }^{9}$ Many epidemiological studies have shown an increased risk of endometrial cancer in both pre and postmenopausal women, with non-insulin dependent diabetes. ${ }^{10-12}$ Some case control studies showed endometrial cancer risk to be associated with serum levels of C-peptide, a marker of pancreatic insulin secretion, ${ }^{13}$ and higher fasting plasma glucose and insulin levels ${ }^{14}$ showing an increased risk with hyperinsulinemia even in non diabetic women. Increased endometrial cancer risk has been associated with early menarche and late menopause, suggesting a relationship of risk with greater life time exposure to estrogens at premenopausal levels. ${ }^{5}$

Epidemiologic studies have produced results which were not only unclear but also very inconsistent among endometrial cancer risk and premenopausal plasma levels of sex steroid hormones and no study is done in Indian population which has estimated the levels of endogenous hormones in endometrial cancer patients. This study is the first of its kind in Indian population as far as our knowledge is concerned. The aim of the present study is to estimate the levels of endogenous hormones like serum testosterone, estrogen and progesterone in their follicular, mid luteal and luteal phases in endometrial cancer cases.

\section{Materials and Methods}

The present study was conducted in the Department of Biochemistry of Saveetha Medical College. 25 diagnosed cases of endometrial cancer after careful examination of FNAC report and histopathological examination belonging to premenopausal age group $<45$ years (premenopausal women are taken by the fact that they have continuous 
9 menstrual cycles over previous 12 months before the sample collection ${ }^{15}$ ) were included in this study. 50 age matched women who have no history of endometrial diseases were taken as controls. Exclusion criteria included patients on hormonal replacement therapy, oral contraceptive usage, individuals suffering with benign disorders like fibroadenoma, lactating mothers, hypertension, chronic illness, autoimmune diseases, renal disorders and liver disorders.

The following information was obtained from both the cases and controls like parity, menopausal status, hereditary information, life style factors including, tobacco usage, alcohol consumption, dietary habits, obesity, and hormonal replacement therapy. Informed consent was obtained from all the cases and controls.
Due permission was obtained from Ethical Clearance Committee for this study. $10 \mathrm{ml}$ of fasting blood samples were collected by venipuncture from all cases and controls during follicular phase (15 to -2 days), mid cycle phase ( -1 to +1 days) and luteal phase $(+2$ to +15 days), by day in cycle relative to LH peak. Estradiol and Testosterone were estimated by CMIA (Chemi Luminescent Microparticle Immuno Assay) and Total Progesterone by CLIA (Chemi Luminescent Immuno Assay). Serum fasting insulin was estimated by using enzymatic method by automated analyzer. The data were analysed by using paired $\mathrm{t}$ test, independent sample test and Mann-Whitney test using SPSS version 23.

\section{Results}

Table 1: Baseline characteristics of endometrial cancer cases and controls

\begin{tabular}{|l|c|c|}
\hline & Cases & Controls \\
\hline Mean age at menarche & 13.6 & 13.5 \\
\hline Mean length of menstrual cycle & 30.1 & 29.2 \\
\hline Mean height (cms) & 151 & 149 \\
\hline Mean weight & 67 & 59 \\
\hline Mean BMI & 27.3 & 24.5 \\
\hline Percentage parous & 77.1 & 91.6 \\
\hline $\begin{array}{l}\text { Percentage reporting first degree } \\
\text { family history }\end{array}$ & 19.6 & 4.0 \\
\hline $\begin{array}{l}\text { Percentage reporting past use of } \\
\text { oral contraceptives }\end{array}$ & 65.7 & 19.7 \\
\hline
\end{tabular}

Table 2: Comparison of Biochemical parameters between cases and controls

\begin{tabular}{|l|c|c|c|c|}
\hline \multirow{2}{*}{ Parameters } & \multicolumn{2}{c|}{$\begin{array}{c}\text { Mean } \pm \text { SD } \\
\text { Standard Error } \\
\text { Mean }\end{array}$} \\
\cline { 2 - 5 } & \multicolumn{1}{|c|}{$\begin{array}{c}\text { Cases } \\
(\mathbf{n = 2 5})\end{array}$} & $\begin{array}{c}\text { Controls } \\
(\mathbf{n = 5 0})\end{array}$ & $\begin{array}{c}\text { Cases } \\
(\mathbf{n = 2 5})\end{array}$ & $\begin{array}{c}\text { Controls } \\
(\mathbf{n = 5 0})\end{array}$ \\
\hline Testosterone $(\mathrm{ng} / \mathrm{mL})$ & $2.5204 \pm 0.96513$ & $0.3792 \pm 0.25127$ & 0.19303 & 0.03554 \\
\hline Follicular estrogen(pg/mL) & $136.04 \pm 52.325$ & $130.28 \pm 56.301$ & 10.465 & 7.962 \\
\hline Mid luteal estrogen(pg/mL) & $247.20 \pm 97.559$ & $232.96 \pm 106.774$ & 19.512 & 15.100 \\
\hline Luteal estrogen(pg/mL) & $129.24 \pm 65.553$ & $133.04 \pm 69.665$ & 13.111 & 9.852 \\
\hline $\begin{array}{l}\text { Follicular } \\
\text { progesterone }(\mathrm{ng} / \mathrm{mL})\end{array}$ & $.0824 \pm .03919$ & $.6858 \pm .41157$ & .00784 & .05821 \\
\hline $\begin{array}{l}\text { Mid luteal } \\
\text { progesterone }(\mathrm{ng} / \mathrm{mL})\end{array}$ & $3.4260 \pm 1.57397$ & $17.4940 \pm 5.99879$ & .31479 & .84836 \\
\hline $\begin{array}{l}\text { Luteal } \\
\text { progesterone(ng/mL) }\end{array}$ & $3.1348 \pm 1.45586$ & $18.4942 \pm 5.61731$ & .29117 & .79441 \\
\hline Insulin(mIU/L) & $13.548 \pm 5.9189$ & $14.172 \pm 6.5235$ & 1.1838 & .9226 \\
\hline
\end{tabular}

Table 3: Independent Samples Test for cases and controls

\begin{tabular}{|c|c|c|c|c|c|c|c|c|c|c|}
\hline \multirow[t]{2}{*}{ Parameter } & & \multicolumn{2}{|c|}{$\begin{array}{l}\text { Levene's test } \\
\text { for Equality of } \\
\text { Variances }\end{array}$} & & \multicolumn{4}{|c|}{ t- test for Equality of Means } & & \\
\hline & & $\mathrm{F}$ & Sig & $\mathrm{t}$ & df & \begin{tabular}{|c|} 
Sig \\
$(2-$ \\
tailed $)$
\end{tabular} & $\begin{array}{c}\text { Mean } \\
\text { difference }\end{array}$ & $\begin{array}{l}\text { Std. error } \\
\text { difference }\end{array}$ & \multicolumn{2}{|c|}{$\begin{array}{c}95 \% \text { confidence } \\
\text { interval of the } \\
\text { difference }\end{array}$} \\
\hline & & & & & & & & & Lower & Upper \\
\hline Testosterone & Equal & 51.567 & .000 & 14.805 & 73 & .000 & 2.14120 & .14463 & 1.85296 & 2.42944 \\
\hline
\end{tabular}




\begin{tabular}{|c|c|c|c|c|c|c|c|c|c|c|}
\hline \multirow[t]{2}{*}{$(\mathrm{ng} / \mathrm{mL})$} & \begin{tabular}{|l|} 
variances \\
assumed
\end{tabular} & & & & & & & & & \\
\hline & \begin{tabular}{|l|} 
Equal \\
variances \\
not \\
assumed \\
\end{tabular} & & & 10.910 & 25.640 & .000 & 2.14120 & .19627 & 1.73749 & 2.54491 \\
\hline \multirow{2}{*}{$\begin{array}{l}\text { Follicular } \\
\text { Estrogen } \\
(\mathrm{pg} / \mathrm{mL})\end{array}$} & \begin{tabular}{|l|} 
Equal \\
variances \\
assumed
\end{tabular} & .177 & .675 & .427 & 73 & .670 & 5.760 & 13.478 & -21.103 & 32.623 \\
\hline & \begin{tabular}{|l|} 
Equal \\
variances \\
not \\
assumed \\
\end{tabular} & & & .438 & 51.394 & .663 & 5.760 & 13.150 & -20.634 & 32.154 \\
\hline \multirow{2}{*}{$\begin{array}{l}\text { Mid luteal } \\
\text { Estrogen } \\
(\mathrm{pg} / \mathrm{mL})\end{array}$} & \begin{tabular}{|l|} 
Equal \\
variances \\
assumed
\end{tabular} & .385 & .537 & .560 & 73 & .577 & 14.240 & 25.434 & -36.450 & 64.930 \\
\hline & \begin{tabular}{|l|} 
Equal \\
variances \\
not \\
assumed \\
\end{tabular} & & & .577 & 52.188 & .566 & 14.240 & 24.672 & -35.264 & 63.744 \\
\hline \multirow{2}{*}{$\begin{array}{l}\text { Luteal } \\
\text { estrogen } \\
\text { (pg/mL) }\end{array}$} & \begin{tabular}{|l|} 
Equal \\
variances \\
assumed
\end{tabular} & .149 & .700 & -.227 & 73 & .821 & -3.800 & 16.740 & -37.163 & 29.563 \\
\hline & \begin{tabular}{|l|} 
Equal \\
variances \\
not \\
assumed \\
\end{tabular} & & & -.232 & 50.821 & .818 & -3.800 & 16.400 & -36.727 & 29.127 \\
\hline \multirow{2}{*}{$\begin{array}{l}\text { Follicular } \\
\text { progesterone } \\
\text { (ng/mL) }\end{array}$} & \begin{tabular}{|l|} 
Equal \\
variances \\
assumed
\end{tabular} & 54.619 & .000 & -7.289 & 73 & .000 & -.60340 & .08278 & -.76838 & -.43842 \\
\hline & \begin{tabular}{|l|} 
Equal \\
variances \\
not \\
assumed \\
\end{tabular} & & & -10.274 & 50.759 & .000 & -.60340 & .05873 & -.72132 & -.48548 \\
\hline \multirow{2}{*}{$\begin{array}{l}\text { Mid luteal } \\
\text { progesterone } \\
\text { (ng/mL) }\end{array}$} & \begin{tabular}{|l|} 
Equal \\
variances \\
assumed
\end{tabular} & 36.953 & .000 & -11.494 & 73 & .000 & -14.06800 & 1.22399 & -16.50740 & -11.62860 \\
\hline & \begin{tabular}{|l|} 
Equal \\
variances \\
not \\
assumed \\
\end{tabular} & & & -15.547 & 61.059 & .000 & -14.06800 & .90488 & -15.87738 & -12.25862 \\
\hline \multirow[t]{2}{*}{$\begin{array}{l}\text { Luteal } \\
\text { progesterone } \\
(\mathrm{ng} / \mathrm{mL})\end{array}$} & \begin{tabular}{|l|} 
Equal \\
variances \\
assumed
\end{tabular} & 24.456 & .000 & -13.406 & 73 & .000 & -15.35940 & 1.14570 & -17.64277 & -13.07603 \\
\hline & \begin{tabular}{|l|} 
Equal \\
variances \\
not \\
assumed \\
\end{tabular} & & & -18.15 & 60.809 & .000 & -15.35940 & .84609 & -17.0513 & -13.66743 \\
\hline \multirow[t]{2}{*}{$\begin{array}{l}\text { Insulin } \\
(\mathrm{mIU} / \mathrm{L})\end{array}$} & \begin{tabular}{|l|} 
Equal \\
variances \\
assumed
\end{tabular} & .785 & .378 & -.402 & 73 & .689 & -.6240 & 1.5008 & -3.7147 & 2.4667 \\
\hline & \begin{tabular}{|l|} 
Equal \\
variances \\
not \\
assumed \\
\end{tabular} & & & -.416 & 52.518 & .679 & -.6240 & 1.5008 & -3.6349 & 2.3869 \\
\hline
\end{tabular}


Table 4: Mann-Whitney test

\begin{tabular}{|l|c|c|c|c|}
\hline \multirow{2}{*}{ Parameters } & \multicolumn{2}{|c|}{ Mean rank } & \multicolumn{2}{c|}{ Sum of ranks } \\
\cline { 2 - 5 } & Cases(n=25) & Contols(n=25) & Cases(n=25) & Controls(n=50) \\
\hline Testosterone(ng/mL) & 62.74 & 25.63 & 1568.50 & 1281.50 \\
\hline $\begin{array}{l}\text { Follicular } \\
\text { estrogen(pg/mL) }\end{array}$ & 40.10 & 36.95 & 1002.50 & 1847.50 \\
\hline $\begin{array}{l}\text { Mid Luteal } \\
\text { Estrogen(pg/mL) }\end{array}$ & 40.40 & 36.80 & 1010.00 & 1840.00 \\
\hline $\begin{array}{l}\text { Luteal } \\
\text { estrogen(pg/mL) }\end{array}$ & 37.40 & 38.30 & 935.00 & 1915.00 \\
\hline $\begin{array}{l}\text { Follicular } \\
\text { progesterone(ng/mL) }\end{array}$ & 13.00 & 50.50 & 325.00 & 2525.00 \\
\hline $\begin{array}{l}\text { Mid luteal } \\
\text { progesterone(ng/mL) }\end{array}$ & 13.24 & 50.38 & 331.00 & 2519.00 \\
\hline $\begin{array}{l}\text { Luteal } \\
\text { progesterone(ng/mL) }\end{array}$ & 13.16 & 50.42 & 329.00 & 2521.00 \\
\hline Insulin(mIU/L) & 36.64 & 38.68 & 916.00 & 1934.00 \\
\hline
\end{tabular}

Table 5: Test Statistics

\begin{tabular}{|l|c|c|c|c|}
\hline \multicolumn{1}{|c|}{ Parameters } & $\begin{array}{c}\text { Mann-Whitney } \\
\text { U test }\end{array}$ & Wilcoxon W & $\mathbf{Z}$ & $\begin{array}{c}\text { Asymp. Sig } \\
\text { (2-tailed) }\end{array}$ \\
\hline Testosterone(ng/mL) & 6.500 & 1281.500 & -6.954 & $.000^{*}$ \\
\hline $\begin{array}{l}\text { Follicular } \\
\text { estrogen(pg/mL) }\end{array}$ & 572.500 & 1847.500 & -.590 & .555 \\
\hline $\begin{array}{l}\text { Mid luteal } \\
\text { estrogen(pg/mL) }\end{array}$ & 565.000 & 1840.000 & -.674 & .500 \\
\hline $\begin{array}{l}\text { Luteal } \\
\text { estrogen(pg/mL) }\end{array}$ & 610.000 & 935.000 & -.169 & .866 \\
\hline $\begin{array}{l}\text { Follicular } \\
\text { progesterone(ng/mL) }\end{array}$ & .000 & 325.000 & -7.026 & $.000^{*}$ \\
\hline $\begin{array}{l}\text { Mid luteal } \\
\text { progesterone(ng/mL) }\end{array}$ & 6.000 & 331.000 & -6.958 & $.000^{*}$ \\
\hline $\begin{array}{l}\text { Luteal } \\
\text { progesterone(ng/mL) }\end{array}$ & 5.000 & 329.000 & -6.981 & $.000^{*}$ \\
\hline Insulin(mIU/L) & 591.000 & 916.000 & -382 & .702 \\
\hline
\end{tabular}

\section{Discussion}

From our study it was found that there was statistical significant increase in the levels of testosterone in cases when compared to controls. There were also statistical significant decrease in the levels of follicular progesterone, mid luteal and luteal progesterone in cases when compared with controls. No statistical differences were observed in the levels of follicular, mid luteal and luteal estrogen and fasting insulin levels between cases and controls.

Our study shows that premenopausal women who have increased levels of serum testosterone are more prone for endometrial cancer. Few prospective studies have shown no statistical association between the levels of testosterone and endometrial cancer in premenopausal women ${ }^{16}$ whereas positive association between testosterone levels and endometrial cancer risk was observed in post menopausal women in many studies. ${ }^{16,17}$ Many case control studies have shown that endometrial cancer risk is also increased in both pre and postmenopausal women with elevated plasma levels of androstenedione $\mathrm{e}^{18,19}$ and testosterone ${ }^{[20]}$ and few did not show the association..$^{21,22}$ Androgens do not appear to have any direct stimulatory effect on endometrial cell proliferation and the results from in vitro studies suggest a reduction in proliferation rates. ${ }^{23,24}$ The association of plasma androgen levels with endometrial cancer risk is thus more likely to be explained by an increase in estrogens, unopposed by progesterone and in premenopausal women, intraovarian androgen excess contributes to follicular atresia, and can lead to chronic anovulation and reduced levels of progesterone. ${ }^{9}$

In our study, statistically significant difference was observed in the levels of follicular, mid luteal and luteal levels of progesterone in cases when compared to controls. In premenopausal women developing endometrial cancer, low progesterone levels rather than increased estrogen may be a more important determinant of risk. ${ }^{25}$ Few epidemiological studies showed higher endometrial cancer risk among women with polycystic ovarian syndrome, a condition 
characterized by obesity, ovarian hyperandrogenism, anovulation, and progesterone deficiency. ${ }^{26}$ The importance of low progesterone is also supported by observations that obesity, a major risk factor for endometrial cancer in both pre and postmenopausal women, does not increase total or bioavailable estrogens in premenopausal women, but in some women can cause chronic anovulation and strongly reduce progesterone synthesis. ${ }^{9}$ No statistical significance were observed in the levels of follicular, mid luteal and luteal estrogen levels between cases and controls in our study. In premenopausal women, developing endometrial cancer, circulating estradiol levels generally are above a threshold of $50 \mathrm{pg} / \mathrm{mL}$ and endometrial cancer risk is not related to between subject differences in circulating estradiol levels, but that low progesterone levels may be a more important determinant of risk. ${ }^{25}$ Our results are consistent with few studies which showed decreased total and bioavailable estradiol in endometrial cancer patients and they also had lower levels of estrone ${ }^{18}$ in premenopausal women developing endometrial cancer.

No statistical significance was observed in the levels of fasting insulin levels between cases and controls in our study. In postmenopausal women, insulin provides a key stimulus to ovarian and adrenal androgen synthesis in Poly cystic ovarian syndrome (PCOS) and leads to estrogen excess and progesterone deficiency. ${ }^{9,27}$ The limitation of our study include less sample size, nonestimation of FSH, LH and their association with estrogen, progesterone and testosterone levels. Women with menstrual cycles who will vary largely both intra and inter individually may also influence the levels of endogenous hormones.

\section{Conclusion}

From our study we conclude that endogenous hormones play a major role in the development of endometrial cancer in premenopausal women as testosterone is increased and progesterone is decreased in cases when compared to controls. We conclude that in future more studies are required to diagnose the risk of endometrial cancer in very early stages to reduce the mortality and morbidity in endometrial cancer patients.

\section{Conflict of interest: Nil}

\section{References}

1. Ellenson LH, Ronnett BM, Soslow RA, Zaino RJ, Kurman RJ. "Endometrial cancer. Blaustein's pathology of the female genital tract" $6^{\text {th }}$ edn. New York: Springer (2011), p 394-452.

2. Bergstrom A, Pisani P, Tenet V, Wolk A \& Adami HO. "Overweight as an avoidable cause of cancer in Europe." Int. J.Cancer (2001) 91(3),421-30.

3. Shu X.O, Brinton L.A, Zheng W, Swanson C.A, Hatch M.C, Gao Y.T, and Fraumeni Jr J.F. "Relation of obesity and body fat distribution to endometrial cancer in Shanghai, China." Cancer Res (1992) 52,3865-9.

4. Swnason C.A, Potischman N, Wilbanks G.D, Twiggs L, Mortel R, Berman M.L, Barrett R.J, Baumgartner R.N, and Brinton L.A. "Relation of endometrial cancer risk to past and contemporary body size and body fat distribution." Cancer Epidemiol. Biomark (1993) Prev, 2,321-7.

5. Grady D, and Ernster V.L.Endometrial cancer. In: D.Schottenfeld and J.F. Fraumeni, Jr. (eds.), "Cancer Epidemiology and Prevention." New York: Oxford Press (1996), pp725-71.

6. McPherson C.P, Sellers T.A, Potter J.D, Bostick R.M, and Folsom A.R. "Reproductive factors and risk of endometrial cancer: The Iowa Women's Health Study." Am. J. Epidemiol (1996)143,1195-202.

7. La Vecchia C, Parazzini F, Negri E, Fasoli M, Gentile A, Franceschi. "Anthropometric indicators of endometrial cancer risk.” Eur J Cancer (1991) 27,487-90.

8. Tornberg SA, Carstensen JM. "Relationship between Quetelet's index and cancer of breast and female genital tract in 47,000 women followed for 25 years." Br J Cancer. (1994) 69,358-61.

9. Rudolf Kaaks, Annekatrin Lukanova, and Mindy S. Kurzer. "Obesity, Endogenous Hormones, and Endometrial Cancer Risk: A Synthetic Review." Cancer Epidemiology. Biomarkers \& Prevention(2002) 11,153143.

10. Weiderpass E, Gridley G, Persson I, Nyren O, Ekbom A, and Adami H.O. "Risk of endometrial and breast cancer in patients with diabetes mellitus.” Int. J. Cancer (1997) 71,360-3.

11. Shoff S.M, and Newcomb P.A. "Diabetes, body size, and risk of endometrial cancer." Am. J. Epidemiol (1998) 148,234-40.

12. La V.C, Negri E, Franceschi S, D’Avanzo B, and Boyle P. "A case-control study of diabetes mellitus and cancer risk.” Br. J. Cancer (1994) 70,950-3.

13. Troisi R, Potischman N, Hoover R.N, Siiteri P, and Brinton L.A. "Insulin and endometrial cancer." Am. J. Epidemiol (1997);146,476-82.

14. Rutanen E.M, Stenman S, Blum W, Karkkainen T, Lehtovirta P and Stenman U.H. "Relationship between carbohydrate metabolism and serum insulin-like growth factor system in postmenopausal women: comparison of endometrial cancer patients with healthy controls." J. Clin. Endocrinol. Metab (1993) 77, 199-204.

15. Kaaks R, Berrino F, Key T et al. "Serum sex steroids in premenopausal women and breast cancer risk within European Prospective Investigation into Cancer and Nutrition (EPIC).” J Natl Cancer Inst. (2005)97,755-65.

16. Naomi E Allen, Timothy J Key, Laure Dosses et al. "Endogenous sex hormones and endometrial cancer risk in women in the European Prospective Investigation into cancer and nutrition.” Endocrine related cancer. (2008) 15,485-97.

17. Lukanova A, Lundin E, Micheli A, Arslan A, Ferrari P, Rinaldi S, Krogh V, Lenner P, Shore RE, Biessy C et al. "Circulating levels of sex steroid hormones and risk of endometrial cancer in postmenopausal women." International Journal of Cancer (2004) 108,425-32.

18. Potischman N, Hoover R.N, Brinton L.A, Siiteri P, Dorgan J.F, Swanson C.A, Berman M.L, et al. "Casecontrol study of endogenous steroid hormones and endometrial cancer.” J. Natl. Cancer Inst. (Bethesda). (1996) $88,1127-35$. 
19. Austin H, Austin J.M, Jr, Partridge E.E, Hatch K.D and Shingleton H. M. "Endometrial cancer, obesity, and body fat distribution." Cancer Res. (1991) 51,568-72.

20. Mollerstrom G, Carlstrom K, Lagrelius A, and Finhorn N. "Is there an altered steroid profile in patients with endometrial carcinoma? " Cancer (Phila). (1993) 72, 173 81.

21. Falsetti L, Omodei U, Dordoni D, Scagliola P, Turla R, Zotti L, and Archetti L. "Profiles and endocrine correlations in endometrial carcinoma." Eur. J. Gynaecol Oncol. (1983) 4, 30-4.

22. Bonney R.C, Scanlon M.J, Jones D.L, Reed M.J, Anderson M.C, and James V.H. "The relationship between estradiol metabolism and adrenal steroids in the endometrium of postmenopausal women with and without endometrial cancer.” Eur. J. Cancer Clin Oncol (1986)22,953-61.

23. Legro R.S, Kunselman A.R, Miller S.A, and Satyaswaroop P.G. "Role of androgens in the growth of endometrial carcinoma: an in vivo animal model." Am. J. Obstet. Gynecol. (2001)184,303-8.

24. Tuckerman E.M, Okon M.A, Li T, and Laird S.M. "Do androgens have a direct effect on endometrial function? An in vitro study." Fertil Steril. (2000) 74, 771-9.

25. Key TJ \& Pike MC. "The dose effect relationship between 'unopposed' estrogens and endometrial mitotic rate: its central role in explaining and predicting endometrial cancer risk." British Journal of Cancer. (1988) 57,205-12.

26. Hardiman P, Pillay OC \& Atiomo W. "Polycystic ovary syndrome and endometrial carcinoma." Lancet. (2003) 361, 1810-12.

27. Kristen E Anderson, Elizabeth Anderson, Pamela J Mink et al. "Diabetes and Endometrial cancer in the Iowa Womens helath study." Cancer Epidemiology, Biomarkers and prevention (2001) 10, 611-6. 